\title{
Different MRI patterns in MS worsening after stopping fingolimod
}

Caterina Lapucci, MD, Damiano Baroncini, MD, Maria Cellerino, MD, Giacomo Boffa, MD, Ilaria Callegari, MD, Matteo Pardini, MD, PhD, Giovanni Novi, MD, Maria Pia Sormani, PhD, Giovanni Luigi Mancardi, MD, Angelo Ghezzi, MD, Mauro Zaffaroni, MD, Antonio Uccelli, MD, Matilde Inglese, MD, PhD, and Luca Roccatagliata, MD, PhD

Neurol Neuroimmunol Neuroinflamm 2019;6:e566. doi:10.1212/NXI.0000000000000566

\section{Abstract \\ Objective}

To analyze MRI images in patients with MS who experienced worsening of neurologic status (WNS) after stopping fingolimod (FTY).

\section{Methods}

In this retrospective study, demographic, clinical, and radiologic data of patients with MS who experienced WNS after stopping FTY were retrospectively collected. We introduced the "SExpanded Disability Status Scale (EDSS)-ratio" to identify patients who, after FTY withdrawal, showed an inflammatory flare-up exceeding the highest lifetime disease activity level. Patients with $\delta$ EDSS-ratio $>1$ were enrolled in the study.

\section{Results}

Eight patients were identified. The mean (SD) age of the 8 (7 female) patients was 35.3 (4.9) years. The mean FTY treatment duration was 3.1 (0.8) years. The mean FTY discontinuation-WNS interval was 4 (0.9) months. The 4 patients with $\delta$ EDSS-ratio $\geq 2$ developed severe monophasic WNS (EDSS score above 8.5), characterized by clinical features and MRI findings not typical of MS, which we classified as "tumefactive demyelination pattern" (TDL) and "Punctuated pattern" (PL). Conversely, patients whose $\delta$ EDSS-ratio was between 1 and 2 had clinical features and brain MRI compatible with a more typical, even if aggressive, MS relapse. In patients with TDL and PL, the flare-up of inflammatory activity led to severe tissue damage resulting in $\mathrm{T} 2$ but also $\mathrm{T} 1$ lesion volume increase at 6-month follow-up.

\section{Conclusions}

Peculiar MRI features (TDL and PL), different from a typical MS flare-up, might occur in some patients who experienced WNS after stopping FTY. Further studies, also involving immunologic biomarkers, are necessary to investigate TDL or PL pathophysiology.

\author{
Correspondence \\ Dr. Lapucci \\ lapuccicate@gmail.com
}

M. Inglese and L. Roccatagliata are co-last authors.

From the Department of Neuroscience, Rehabilitation, Ophthalmology, Genetics (C.L., M.C., G.B., M.P., G.N., G.L.M., A.U., M.I.), Maternal and Child Health (DiNOGMI), University of Genoa; Multiple Sclerosis Centre (D.B., A.G., M.Z.), Gallarate Hospital, ASST of Valle Olona, Gallarate; Department of Neurology (M.C., G.B., M.P., G.L.M., A.U.), Ospedale Policlinico San Martino-Sistema Sanitario Regione; Liguria -Istituto di Ricovero e Cura a Carattere Scientifico per I'Oncologia; IRCCS Foundation C. Mondino National Neurological Institute (I.C.), Pavia; Department of Health Sciences (DISSAL) (M.P.S., L. R.), Ospedale Policlinico San Martino IRCCS, Genoa, Italy; Department of Radiology and Neuroscience (M.I.), Icahn School of Medicine at Mount Sinai, New York; and Department of Neuroradiology (L.R.), Ospedale Policlinico San Martino IRCCS, Genoa, Italy.

Funding information and disclosures are provided at the end of the article. Full disclosure form information provided by the authors is available with the full text of this article at Neurology.org/NN. 


\section{Glossary}

CL = classic MS pattern; EDSS = expanded disability status scale; FTY = fingolimod; FU = follow-up; $\mathbf{L V}=$ lesion volume; PL = punctuated pattern; TDL = tumefactive demyelination pattern; WNS = worsening of neurologic status.

Fingolimod (FTY) is an oral sphingosine-1-phosphate receptor (S1P1) modulator approved for MS. In the past few years, worsening of neurologic status (WNS) has been described in a small series of patients after FTY discontinuation. ${ }^{1}$ This phenomenon remains controversial and regarded as MS "reactivation" ${ }^{2}$ or considered a distinct "rebound" phenomenon. ${ }^{3}$ Nevertheless, WNS after stopping FTY can lead to severe disability or can even be life-threatening, and thus the Food and Drug Administration recently issued a warning on this topic. ${ }^{4}$ We report a retrospective series of 8 patients who developed WNS after FTY withdrawal focusing on the different MRI patterns in the acute phase. The aim of the study was to analyze MRI images in patients with MS who experienced WNS after stopping FTY.

\section{Methods}

\section{Standard protocol approvals, registrations, and patient consent}

A written informed consent was obtained from all patients.

\section{Patients}

From the systematic revision of clinical records of patients, we collected clinical-radiological data of patients with MS who developed WNS after FTY withdrawal between November 2013 and November 2017.

\section{Clinical data analysis}

We defined WNS by calculating the "post-FTY withdrawal $\delta$ Expanded Disability Status Scale (EDSS)/pre-FTY withdrawal $\delta E D S S$ ratio" (from now on called "SEDSS-ratio"), where

1. post-FTY-withdrawal $\delta$ EDSS is the highest EDSS score change $(\delta)$ occurred after FTY withdrawal

2. pre-FTY-withdrawal $\delta$ EDSS is the highest EDSS score change $(\delta)$ occurred during the whole previous MS course (i.e., worst lifetime relapse).

Patients with $\delta$ EDSS-ratio > 1 were enrolled in the study.

WNS after FTY discontinuation was distinguished as monophasic (one or more relapses, but with less than 1 month between relapses), biphasic ( 2 relapses occurring at least 1 month apart), and multiphasic ( $\geq 3$ relapses).

\section{MRI acquisition and analysis}

T2/FLAIR, TSE-T1 (before and after Gadolinium [Gd] administration), and DWI, performed before FTY withdrawal, during the WNS, and at 6-month follow-up (FU), were analyzed to obtain T2 and T1 lesion volume (LV), number and pattern of Gd-enhancing lesions and volume of tissue with restricted diffusion.

Data are reported as mean $\pm \mathrm{SD}$.

\section{Data availability}

Raw data are available upon appropriate request.

\section{Results}

We identified 8 patients. Seven patients were women. The mean age was $35.3 \pm 4.9$ years. The mean duration of FTY treatment was $3.1 \pm 0.8$ years. The most common cause of FTY discontinuation was the attempt to become pregnant ( 6 out of 7 female patients). The mean FTY discontinuationWNS interval was $4 \pm 0.9$ months.

We stratified patients according to the $\delta$ EDSS ratio:

1. $\delta$ EDSS-ratio $\geq 2$ (Pt.1-Pt.4)

2. $>1 \delta$ EDSS-ratio $<2$ (Pt.5-Pt.8).

\section{Clinical features}

The 4 patients with a $\delta$ EDSS-ratio $\geq 2$, developed a monophasic WNS and reached EDSS scores of up to 9, 8.5 and 9.5 (Pt.1, Pt.3, and Pt.4); one patient (Pt.2) died. Pt.1, Pt.2, and Pt.4 developed tetraplegia and multiple cranial nerve involvement with decrease in consciousness rapidly resulting in coma. Pt. 3 presented a marked cognitive impairment associated with motor disability.

The 4 patients with $\delta$ EDSS-ratio between 1 and 2, showed multiphasic (Pt.5), biphasic (Pt.6 and Pt.7), and monophasic (Pt.8) courses, characterized by multifocal neurologic deficits, without altered state of consciousness.

At 2-year FU, for patients with $\delta$ EDSS-ratio $\geq 2$, disability worsened when compared to patients with $>1 \delta$ EDSS-ratio $<2$ (increase in mean EDSS points: $3 \pm 2.9$ vs $1.1 \pm 1.2$ ) (figure 1 ).

Demographic and clinical features and treatment performed are detailed in the table.

\section{MRI features}

The 4 patients with a $\delta$ EDSS-ratio $\geq 2$ showed MRI features that we defined as "tumefactive demyelination pattern" (TDL) (Pt.2-Pt.4) and "punctuated pattern" (PL) (Pt.3) (figure 2, figure e-1, links.lww.com/NXI/A109).

TDL was characterized by large T2/FLAIR hyperintense lesions surrounded by marked edema, mass effect on adjacent 
Figure 1 EDSS score (A), T2LV (B) and T1LV (C) courses in patients who experienced WNS after FTY withdrawal

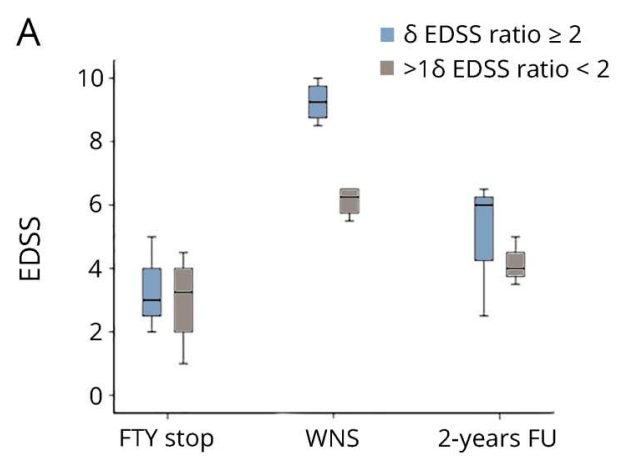

B

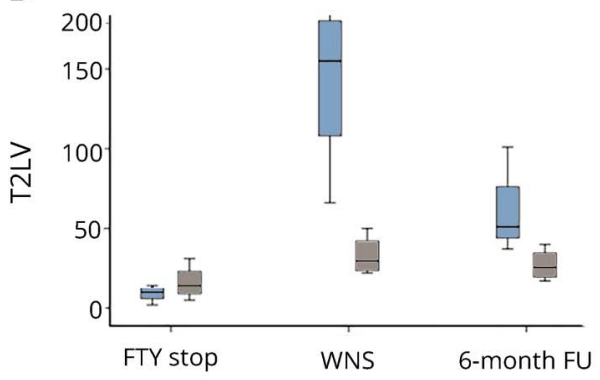

C

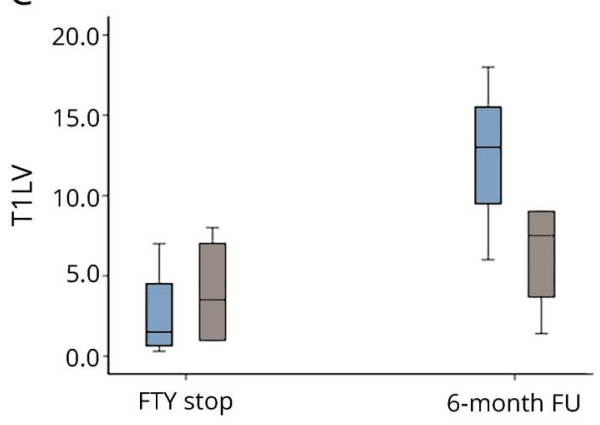

(A) EDSS scores were reported at FTY stop, WNS and 2-year follow-up. Patients with $\delta E D S S$-ratio $\geq 2$ reached very high EDSS scores at WNS and accumulated more disability at 2-year follow-up when compared to patients with $>1$ SEDSS-ratio $>2$. (B) T2LV was calculated at FTY stop, WNS and 6month FU. At the 6-month follow-up, all patients and particularly those with $\delta$ EDSS-ratio $\geq 2$, had a T2LV increase compared to the pre-FTY suspension MRI, although decreased with respect to the MRI scan at WNS, likely due to the resolution of a portion of T2 hyperintensity, probably reflecting oedema. (C) T1 LV was calculated at FTY stop and 6-month FU to consider chronic black holes. At 6-month follow-up all patients, and particularly those with SEDSSratio $\geq 2$, showed a T1LV increase with respect to the MRI scan at WNS. EDSS $=$ expanded disability status scale; FTY = fingolimod; FU = follow-up; T1LV = T1 lesion volume; T2LV = T2 lesion volume; WNS = worsening of neurologic status; $\delta E D S S-r a t i o=$ post-FTY withdrawal $\delta E D S S /$ pre-FTY withdrawal $\delta E D S S$ ratio.

structures, and multiple enhancing lesions with an open ring (40\%), nodular (30\%), or closed ring (30\%) enhancement. A large proportion of lesions had areas of restricted diffusion (up to 30\%) (figure 2). PL presented innumerable small T2/ FLAIR hyperintense lesions, mostly associated with contrast enhancement and restricted diffusion (15\%) (figure 2).

The 4 patients with the $\delta$ EDSS-ratio between 1 and 2 showed MRI features that we defined as "classic MS pattern" (figure 2, figure e-1, links.lww.com/NXI/A109). Brain MRIs showed
T2/FLAIR lesions with no edema nor mass effect, some with nodular/ring enhancement and only a small volume of tissue with restricted diffusion.

At the 6-month FU, all patients exhibited a T2LV increase compared to the pre-FTY suspension MRI, although it decreased according to the MRI scan at WNS, likely due to the partial resolution of T2 hyperintensity. This finding was more evident for patients with a $\delta E D S S$-ratio $\geq 2$, particularly with TDL.

T1LV increased in all patients at the 6-month FU. Patients who showed a higher volume of tissue characterized by restricted diffusion at WNS had a higher T1LV \% increase at 6-month FU (figure 1).

MRI data are detailed in the table.

\section{Discussion}

Severe WNS occurring in patients with MS after FTY withdrawal is a rare and not completely understood phenomenon. Although a recent post-hoc analysis of FREEDOMSFREEDOMS II trials found no difference in the development of the so-called rebound between patients discontinuing FTY and the placebo group, ${ }^{5}$ a small series reported increases in clinical and radiologic disease activity after FTY cessation in $10.9 \%-25.8 \%$ of patients. ${ }^{1,6}$ Furthermore, a recent study confirmed that the "rebound" phenomenon after FTY suspension does exist, with a risk estimated at $5 \%{ }^{7}$ and recently FDA issued a warning about severe MS worsening after stopping FTY. ${ }^{4}$ Cast aside the controversy regarding the frequency, it is relevant to consider that the "rebound" phenomenon leads to permanent severe disability, may be life-threatening or even fatal, as occurred to one patient of our cohort.

We retrospectively identified 8 patients who experienced, after FTY withdrawal, a WNS exceeding the highest lifetime level of MS activity, calculating the $\delta$ EDSS-ratio to stratify WNS severity. All patients were clinically stable during FTY treatment, with 6 patients well enough to decide to plan pregnancy.

Patients with $\delta E D S S$-ratio $\geq 2$ developed severe monophasic WNS (EDSS score above 8.5), characterized by clinical features (i.e., tetraplegia resulting in coma) and MRI findings not typical of MS. Large T2/FLAIR lesions with edema, ring/ nodular enhancement, and restricted diffusion characterized TDL, while PL showed innumerable millimetric enhancing lesions and a high rate of tissue with restricted diffusion. Conversely, patients with $>1 \delta$ EDSS-ratio $<2$ had clinical features and brain MRI compatible with a more typical, even if aggressive, MS relapse.

In patients with TDL and PL, the flare-up of inflammatory activity led to severe tissue damage resulting in $\mathrm{T} 2$ but also T1LV increase at 6 months; moreover, they demonstrated larger areas of tissue with restricted diffusion, which may 
Table Clinical and MRI features of patients with MS who experienced WNS after FTY withdrawal

\begin{tabular}{|c|c|c|c|c|c|c|c|c|}
\hline & Pt.1 & Pt.2 & Pt.3 & Pt.4 & Pt.5 & Pt.6 & Pt.7 & Pt.8 \\
\hline \multicolumn{9}{|l|}{ Jemographics } \\
\hline Sex & $\mathrm{F}$ & $\mathrm{F}$ & $\mathrm{F}$ & $\mathrm{F}$ & $\mathrm{F}$ & $\mathrm{F}$ & $\mathrm{F}$ & M \\
\hline Age & 40 & 26 & 35 & 33 & 30 & 33 & 39 & 46 \\
\hline \multicolumn{9}{|l|}{ Clinical data } \\
\hline MS type at withdrawal & SPMS & RRMS & RRMS & RRMS & RRMS & RRMS & RRMS & SPMS \\
\hline $\begin{array}{l}\text { MS duration at FTY stop } \\
\text { (y) }\end{array}$ & 19 & 9 & 13 & 19 & 9 & 18 & 13 & 12 \\
\hline FTY duration (y) & 4 & 2 & 4 & 3 & 3 & 3 & 3 & 4 \\
\hline $\begin{array}{l}\text { Relapses and/or MRI } \\
\text { activity during FTY }\end{array}$ & No & No & No & Yes & No & No & No & No \\
\hline Cause of FTY withdrawal & Progressive course & Pregnancy attempt & $\begin{array}{l}\text { Pregnancy } \\
\text { attempt }\end{array}$ & Pregnancy attempt & Pregnancy attempt & Pregnancy attempt & $\begin{array}{l}\text { Pregnancy } \\
\text { attempt }\end{array}$ & $\begin{array}{l}\text { Progressive } \\
\text { course }\end{array}$ \\
\hline FTY stop-WNS (m) & 3 & 4 & 4 & 3 & 3 & 5 & 5 & 5 \\
\hline Pregnancy outcome & NA & $\begin{array}{l}\text { Therapeutic abortion } \\
\text { to treat WNS }\end{array}$ & $\begin{array}{l}\text { Miscarriage } 1 \mathrm{wk} \\
\text { before WNS }\end{array}$ & $\begin{array}{l}\text { Therapeutic abortion } \\
1 \text { wk before WNS }\end{array}$ & $\begin{array}{l}\text { Unsuccessful pregnancy } \\
\text { attempt }\end{array}$ & $\begin{array}{l}\text { Unsuccessful } \\
\text { pregnancy attempt }\end{array}$ & $\begin{array}{l}\text { Unsuccessful } \\
\text { pregnancy } \\
\text { attempt }\end{array}$ & NA \\
\hline $\begin{array}{l}\text { Gestational age at } \\
\text { therapeutic abortion/ } \\
\text { miscarriage (wk) }\end{array}$ & NA & 30 & 8 & 7 & NA & NA & NA & NA \\
\hline Clinical features at WNS & $\begin{array}{l}\text { Tetraplegia cranial n. } \\
\text { deficits (locked-in), } \\
\text { coma }\end{array}$ & $\begin{array}{l}\text { Tetraplegia cranial n. } \\
\text { deficits (locked-in), } \\
\text { coma }\end{array}$ & $\begin{array}{l}\text { Severe cognitive } \\
\text { and motor } \\
\text { impairment }\end{array}$ & $\begin{array}{l}\text { Tetraplegia cranial n. } \\
\text { deficits (locked-in) } \\
\text { coma }\end{array}$ & $\begin{array}{l}\text { Left hypoesthesia (I), } \\
\text { paraparesis (II), } \\
\text { monoparesis (III) }\end{array}$ & $\begin{array}{l}\text { Cerebellar (I), } \\
\text { sensori-motor } \\
\text { syndrome (II) }\end{array}$ & $\begin{array}{l}\text { Motor (I), } \\
\text { cognitive } \\
\text { impairment (II) }^{\text {a }}\end{array}$ & $\begin{array}{l}\text { Right sensori- } \\
\text { motor } \\
\text { syndrome }\end{array}$ \\
\hline Spine involvement & Yes & No & Yes & Yes & Yes & No & No & No \\
\hline EDSS at WNS & 9 & 10 & 8.5 & 9.5 & 6.5 & 6.5 & 5.5 & 6 \\
\hline SEDSS ratio & 2 & 3.5 & 3.2 & 2.1 & 1.8 & 1.2 & 1.2 & 1.5 \\
\hline WNS course & Monophasic & Monophasic & Monophasic & Monophasic & Multiphasic & Biphasic & Biphasic & Monophasic \\
\hline WNS therapy & CTS, PEX, AHSCT & CTS, CYC & CTS, PEX, RTX & CTS, PEX, RTX & CTS, ALEM & CTS, AHSCT & CTS, RTX & CTS, NAT \\
\hline $\begin{array}{l}\text { FTY stop-2 y FU EDSS } \\
\text { increase }\end{array}$ & 1 & 7 & 0.5 & 3.5 & 3 & 0.5 & 0.5 & 0.5 \\
\hline \multicolumn{9}{|l|}{ MRI data } \\
\hline Pattern & $\mathrm{PL}$ & TDL & TDL & TDL & $\mathrm{CL}$ & $\mathrm{CL}$ & $\mathrm{CL}$ & $\mathrm{CL}$ \\
\hline
\end{tabular}




\begin{tabular}{|c|c|c|c|c|c|c|c|c|}
\hline & Pt.1 & Pt.2 & Pt.3 & Pt.4 & Pt.5 & Pt.6 & Pt.7 & Pt.8 \\
\hline \multicolumn{9}{|l|}{$\mathrm{T} 2 \mathrm{LV}^{\mathrm{b}}(\mathrm{mL})$} \\
\hline FTY stop & 14 & 10 & 2 & 10 & 5 & 15 & 31 & 13 \\
\hline WNS & 66 & 200 & 160 & 150 & $22^{c}$ & $34^{c}$ & $50^{c}$ & 25 \\
\hline 6-mo FU & 51 & NA (exitus) & 37 & 101 & 22 & 17 & 40 & 29 \\
\hline $\begin{array}{l}\% \text { Increase WNS-FTY } \\
\text { stop }\end{array}$ & 264 & 1900 & 7,900 & 1,400 & $340^{c}$ & $126^{c}$ & $61^{c}$ & 92 \\
\hline $\begin{array}{l}\% \text { Increase } 6 \text { mo FU- } \\
\text { WNS }\end{array}$ & 253 & NA (exitus) & 1750 & 910 & $340^{c}$ & $13^{\mathrm{c}}$ & $29^{c}$ & 124 \\
\hline Gd + lesions at WNS $(n)$ & $>50$ & $>50$ & $>50$ & 35 & $3(I), 3(I I), 6(I I I)^{d}$ & $10(I), 2(I I)^{d}$ & $8(I), 20(I I)^{d}$ & 6 \\
\hline $\begin{array}{l}\text { Hypointense lesions at } \\
\text { WNS (ADC) (\% of Gd } \\
\text { lesions) }\end{array}$ & Yes $(\approx 15 \%)^{\mathrm{e}}$ & Yes $(\approx 25 \%)^{\mathrm{e}}$ & Yes $(\approx 30 \%)^{\mathrm{e}}$ & Yes (15\%) & Yes (8\%) & Yes (2\%) & Yes (1\%) & Yes (1\%) \\
\hline $\begin{array}{l}\text { LV restricted diffusion } \\
(\mathrm{mL})\end{array}$ & 2.4 & 4.2 & 5.8 & 2.8 & 0.6 & 0.3 & 0.3 & 0.1 \\
\hline \multicolumn{9}{|l|}{$\mathrm{T} 1 \mathrm{LV}^{\mathrm{b}}(\mathrm{mL})$} \\
\hline FTY stop & 1 & 7 & 2 & 0.3 & 1 & 6 & 8 & 1 \\
\hline 6-months FU & 18 & NA (exitus) & 13 & 6 & 6 & 9 & 9 & 1.4 \\
\hline $\begin{array}{l}\% \text { Increase } 6 \text { month FU- } \\
\text { FTY stop }\end{array}$ & 1700 & NA (exitus) & 550 & 1900 & 500 & 50 & 12 & 40 \\
\hline \multicolumn{9}{|c|}{ 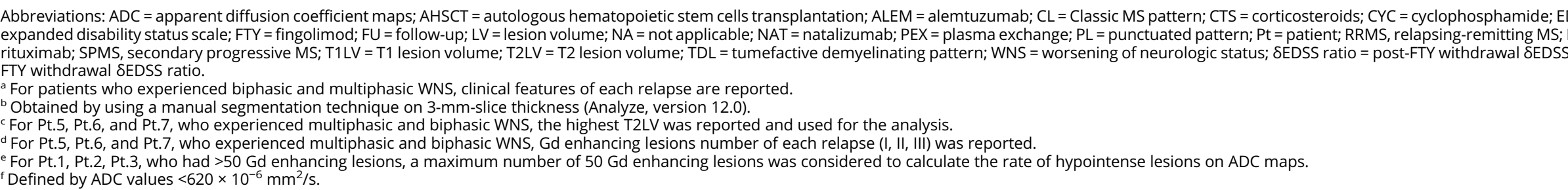 } \\
\hline
\end{tabular}


A. Tumefactive demyelination pattern

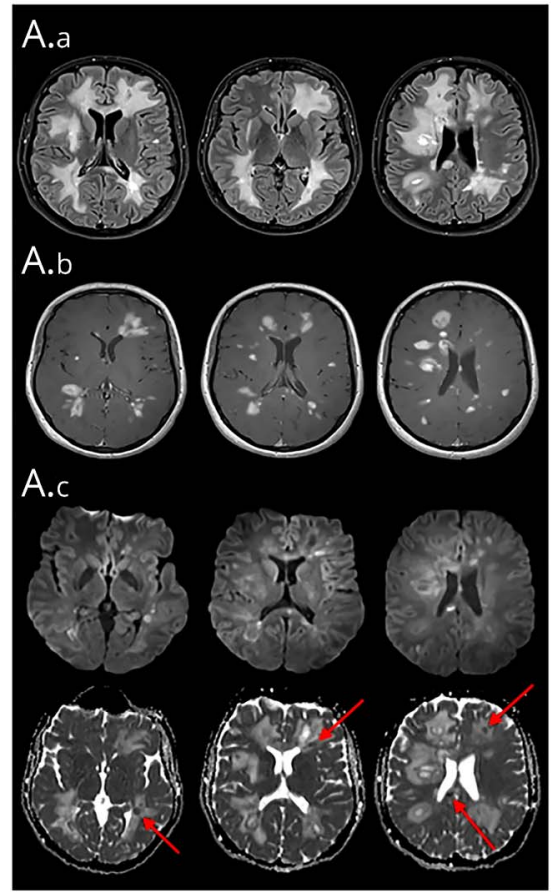

B. Punctuated pattern

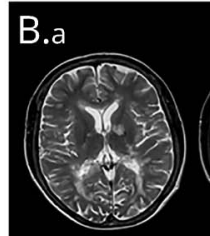

B.b

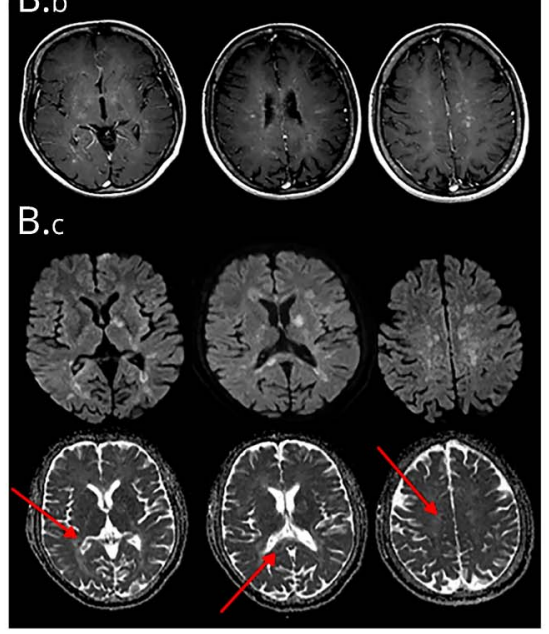

C. Classic MS pattern
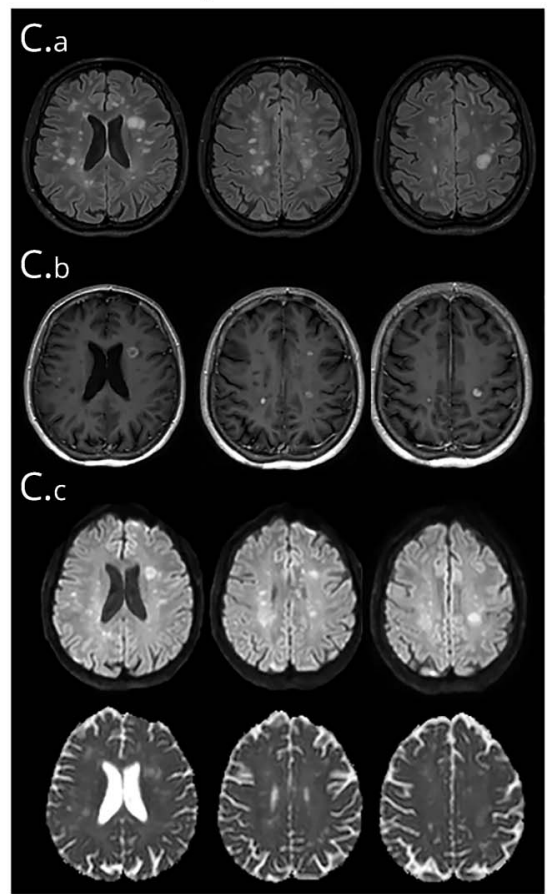

(A) Tumefactive demyelination pattern (TDL), Pt.3. (A.a) Axial T2/FLAIR images, showing large and edematous lesions, causing mass effect on adjacent structures; (A.b) Axial TSE-T1 after Gd administration images, showing multiple ring and nodular enhancing lesions; (A.C) axial DWI (on the left) and correspondent ADC maps (on the right) images, showing hyperintense lesions on DWI with correspondent hypointense signal on ADC maps (red arrows), expression of restricted diffusion. (B) Punctuated pattern (PL), Pt.1, SPMS patient. (B.a) axial TSE-T2 images, medium in size (already detectable in previous scans) and new small hyperintense lesions, with no edema and mass effect; (B.b) axial TSE-T1 after gadolinium administration images, showing innumerable millimetric enhancing lesions, both in infratentorial and supratentorial areas. (B.C) axial DWI (on the left) and correspondent ADC maps (on the right) images, showing hyperintense lesions on DWI with correspondent hypointense signal on ADC maps (red arrows), expression of restricted diffusion. (C) Classic MS pattern (CL). (Pt.6) (C.a) Axial FLAIR images, showing medium in size lesions, with no edema and mass effect; (B.b) axial TSE-T1 after gadolinium administration images, showing nodular and ring enhancing lesions. (C.C) Axial DWI (on the left) and correspondent ADC maps (on the right) images, showing hyperintense lesions on DWI with correspondent hyperintense signal on ADC maps ("T2-shine through effect").

suggest that cytotoxic edema and/or high inflammatory cells density within acute lesions resulted in more profound brain tissue damage. ${ }^{8}$

The pathophysiology of the "rebound" phenomenon is still unclear. Brain histologic examination of the patient who died (reported in a separate publication) revealed prominent astrocytic gliosis, with large hypertrophic reactive astrocytes showing intense S1P1 expression. ${ }^{9}$ The role of astrocytes in modulating the influx of leukocytes into the CNS has been demonstrated in a model of experimental autoimmune encephalitis $^{10}$ and warrants further investigation in the context of FTY withdrawal. MRI features similar to the TDL and PL patterns that we described have been reported in patients with evidence of $\mathrm{B}$ cell hyper-repopulation after alemtuzumab treatment. $^{11}$

The small size of our cohort represents a limitation of the study. We used the $\delta$ EDSS-ratio as a method to stratify the patients who worsened after FTY suspension and its role as a predictor of the outcome after WNS is unknown. Interestingly, patients with worse clinical course and outcome were those who showed peculiar MRI features that we defined
TDL and PL, different from a typical MS flare-up. Further studies are necessary to investigate whether specific cellular subsets play a role in patients who develop a severe WNS after FTY cessation.

\section{Study funding}

This study did not receive any funding support.

\section{Disclosure}

C. Lapucci reports no disclosures. D. Baronicini received travel grants from Genzyme, Novartis, and Merck for participation at national and international congresses; he received personal compensation from Almirall for scientific publication and honoraria from Sanofy for participating in an advisory board. M. Cellerino, G. Boffa, and I. Callegari report no disclosures. M. Pardini received research support from Novartis and personal fees from Teva and Merck. G. Novi reports no disclosures. M.P. Sormani received consulting fees from Biogen Idec, Merck Serono, Teva, Genzyme, Roche, Novartis, GeNeuro, and Medday; G.L. Mancardi received honoraria for lecturing, travel expenses for attending meetings, and financial support for research from Bayer Schering, Biogen Idec, Sanofi-Aventis, Merck Serono Pharmaceuticals, Novartis, 
Genzyme, and Teva. A. Ghezzi received honoraria for speaking and consultancy by Novartis, Genzyme, Roche, Merck Serono, Teva, and Mylan. M. Zaffaroni received honoraria for consultancy and participation in advisory boards or travel grants from Genzyme, Biogen Idec, Merck Serono, Sanofi-Aventis, Teva, and Novartis. A. Uccelli received grants and contracts from FISM, Novartis, Fondazione Cariplo, Italian Ministry of Health; received honoraria and consultation fees from Biogen, Roche, Teva, Merck, Genzyme, and Novartis. M. Inglese received research grants from NIH, DOD, NMSS, FISM, and Teva Neuroscience. L. Roccatagliata received research grants from FISM. Disclosures available: Neurology.org/NN.

\section{Publication history}

Received by Neurology: Neuroimmunology \& Neuroinflammation February 26, 2019. Accepted in final form March 5, 2019.

Appendix Authors

\begin{tabular}{|c|c|c|c|}
\hline Name & Location & Role & Contribution \\
\hline $\begin{array}{l}\text { Caterina } \\
\text { Lapucci, MD }\end{array}$ & $\begin{array}{l}\text { DINOGMI, } \\
\text { University of } \\
\text { Genoa }\end{array}$ & $\begin{array}{l}\text { Author } \\
\text { (corresponding } \\
\text { author) }\end{array}$ & $\begin{array}{l}\text { Designed and } \\
\text { conceptualized } \\
\text { study; analyzed } \\
\text { the data; and } \\
\text { drafted the } \\
\text { manuscript for } \\
\text { intellectual } \\
\text { content }\end{array}$ \\
\hline $\begin{array}{l}\text { D. Baroncini, } \\
\text { MD }\end{array}$ & $\begin{array}{l}\text { Multiple } \\
\text { Sclerosis Centre, } \\
\text { Gallarate } \\
\text { Hospital, ASST of } \\
\text { Valle Olona, } \\
\text { Gallarate, Italy }\end{array}$ & Author & $\begin{array}{l}\text { Acquisition of } \\
\text { data; and } \\
\text { revised the } \\
\text { manuscript for } \\
\text { intellectual } \\
\text { content }\end{array}$ \\
\hline $\begin{array}{l}\text { M. Cellerino, } \\
\text { MD }\end{array}$ & $\begin{array}{l}\text { DINOGMI, } \\
\text { University of } \\
\text { Genoa }\end{array}$ & Author & $\begin{array}{l}\text { Acquisition of } \\
\text { data; and } \\
\text { revised the } \\
\text { manuscript for } \\
\text { intellectual } \\
\text { content }\end{array}$ \\
\hline G. Boffa, MD & $\begin{array}{l}\text { DINOGMI, } \\
\text { University of } \\
\text { Genoa }\end{array}$ & Author & $\begin{array}{l}\text { Acquisition of } \\
\text { data; and } \\
\text { revised the } \\
\text { manuscript for } \\
\text { intellectual } \\
\text { content }\end{array}$ \\
\hline $\begin{array}{l}\text { I.Callegari, } \\
\text { MD }\end{array}$ & $\begin{array}{l}\text { IRCCS } \\
\text { Foundation C. } \\
\text { Mondino National } \\
\text { Neurological } \\
\text { Institute, Pavia, } \\
\text { Italy }\end{array}$ & Author & $\begin{array}{l}\text { Acquisition of } \\
\text { data; and } \\
\text { revised the } \\
\text { manuscript for } \\
\text { intellectual } \\
\text { content }\end{array}$ \\
\hline $\begin{array}{l}\text { M. Pardini, } \\
\text { MD, PhD }\end{array}$ & $\begin{array}{l}\text { DINOGMI, } \\
\text { University of } \\
\text { Genoa }\end{array}$ & Author & $\begin{array}{l}\text { Analyzed the } \\
\text { data; and } \\
\text { revised the } \\
\text { manuscript for } \\
\text { intellectual } \\
\text { content }\end{array}$ \\
\hline G. Novi, MD & $\begin{array}{l}\text { DINOGMI, } \\
\text { University of } \\
\text { Genoa }\end{array}$ & Author & $\begin{array}{l}\text { Acquisition of } \\
\text { data; and } \\
\text { revised the } \\
\text { manuscript for } \\
\text { intellectual } \\
\text { content }\end{array}$ \\
\hline
\end{tabular}

Appendix (continued)

\begin{tabular}{|c|c|c|c|}
\hline Name & Location & Role & Contribution \\
\hline $\begin{array}{l}\text { M.P. Sormani, } \\
\text { PhD }\end{array}$ & $\begin{array}{l}\text { Ospedale } \\
\text { Policlinico }\end{array}$ & Author & $\begin{array}{l}\text { Revised the } \\
\text { manuscript for } \\
\text { intellectual } \\
\text { content }\end{array}$ \\
\hline $\begin{array}{l}\text { G.L. } \\
\text { Mancardi, } \\
\text { MD }\end{array}$ & $\begin{array}{l}\text { DINOGMI, } \\
\text { University of } \\
\text { Genoa }\end{array}$ & Author & $\begin{array}{l}\text { Revised the } \\
\text { manuscript for } \\
\text { intellectual } \\
\text { content }\end{array}$ \\
\hline A. Ghezzi, MD & $\begin{array}{l}\text { Multiple } \\
\text { Sclerosis Centre, } \\
\text { Gallarate } \\
\text { Hospital, ASST of } \\
\text { Valle Olona, } \\
\text { Gallarate, Italy }\end{array}$ & Author & $\begin{array}{l}\text { Revised the } \\
\text { manuscript for } \\
\text { intellectual } \\
\text { content }\end{array}$ \\
\hline $\begin{array}{l}\text { M. Zaffaroni, } \\
\text { MD }\end{array}$ & $\begin{array}{l}\text { Multiple } \\
\text { Sclerosis Centre, } \\
\text { Gallarate } \\
\text { Hospital, ASST of } \\
\text { Valle Olona, } \\
\text { Gallarate, Italy }\end{array}$ & Author & $\begin{array}{l}\text { Revised the } \\
\text { manuscript for } \\
\text { intellectual } \\
\text { content }\end{array}$ \\
\hline A. Uccelli, MD & $\begin{array}{l}\text { Department of } \\
\text { Neurosciences, } \\
\text { Rehabilitation, } \\
\text { Ophthalmology, } \\
\text { Genetics, } \\
\text { Maternal and } \\
\text { Child Health } \\
\text { Unit, Center of } \\
\text { Excellence for } \\
\text { Biomedical } \\
\text { Research, } \\
\text { University of } \\
\text { Genoa, Genoa, } \\
\text { Italy; Ospedale } \\
\text { Policlinico San } \\
\text { Martino-IRCCS, } \\
\text { Genoa, Italy }\end{array}$ & Author & $\begin{array}{l}\text { Revised the } \\
\text { manuscript for } \\
\text { intellectual } \\
\text { content }\end{array}$ \\
\hline $\begin{array}{l}\text { M. Inglese, } \\
\text { MD, PhD }\end{array}$ & $\begin{array}{l}\text { DINOGMI, } \\
\text { University of } \\
\text { Genoa; Icahn } \\
\text { School of } \\
\text { Medicine, Mount } \\
\text { Sinai, NY }\end{array}$ & Author & $\begin{array}{l}\text { Designed and } \\
\text { conceptualized } \\
\text { the study; and } \\
\text { revised the } \\
\text { manuscript for } \\
\text { intellectual } \\
\text { content }\end{array}$ \\
\hline $\begin{array}{l}\text { L. } \\
\text { Roccatagliata, } \\
\text { MD, PhD }\end{array}$ & $\begin{array}{l}\text { Ospedale } \\
\text { Policlinico San } \\
\text { Martino IRCCS, } \\
\text { Genoa }\end{array}$ & Author & $\begin{array}{l}\text { Designed and } \\
\text { conceptualized } \\
\text { the study; } \\
\text { analyzed the } \\
\text { data; and } \\
\text { revised the } \\
\text { manuscript for } \\
\text { intellectual } \\
\text { content }\end{array}$ \\
\hline
\end{tabular}

\section{References}

1. Hatcher SE, Waubant E, Nourbakhsh B, et al. Rebound syndrome in patients with multiple sclerosis after cessation of fingolimod treatment. JAMA 2016;73: 790-794.

2. Berger B, Baumgartner A, Rauer S, et al. Severe disease reactivation in four patients with relapsing-remitting multiple sclerosis after fingolimod cessation. J Neuroimmunol 2015;282: 118-122.

3. Havla JB, Pellkofer HL, Meinl I, et al. Rebound of disease activity after withdrawal of fingolimod (FTY720) treatment. Arch Neurol 2012;69:262-264.

4. FDA. Gilenya (Fingolimod): Drug Safety Communication-Severe Worsening of Multiple Sclerosis After Stopping the Medicine. 2018. Available at: fda.gov/Safety/ MedWatch/SafetyInformation/SafetyAlertsforHumanMedicalProducts/ucm626264. htm. Accessed November 21, 2018. 
5. Vermersch P, Radue EW, Putzki N, et al. A comparison of multiple sclerosis disease activity after discontinuation of fingolimod and placebo. Mult Scler J Exp Transl Clin 2017;3:2055217317730096.

6. Uygunoglu U, Tutuncu M, Altintas A, et al. Factors predictive of severe multiple sclerosis disease reactivation after fingolimod cessation. Neurologist 2018;23:12-16.

7. Frau J, Sormani MP, Signori A, et al. Clinical activity after fingolimod cessation: disease reactivation or rebound?. Eur J Neurol 2018;25:1270-1275.

8. Abdoli M, Chakraborty S, MacLean HJ, et al. The evaluation of MRI diffusion values of active demyelinating lesions in multiple sclerosis. Mult Scler Relat Disord 2016;10: 97-102.
9. Giordana MT, Cavalla P, Uccelli A, et al. Overexpression of sphingosine-1phosphate receptors on reactive astrocytes drives neuropathology of multiple sclerosis rebound after fingolimod discontinuation. Mult Scler 2018;24: 1133-1137.

10. Voskuhl RR, Peterson RS, Song B, et al. Reactive astrocytes form scar-like perivascular barriers to leukocytes during adaptive immuneinflammation of the CNS. J Neurosci 2009;29:11511-11522.

11. Wehrum T, Beume LA, Stich O, et al. Activation of disease during therapy with alemtuzumab in 3 patients with multiple sclerosis. Neurology 2018;90: e601-e605. 


\section{Neurology \\ Neuroimmunology \& Neuroinflammation}

\section{Different MRI patterns in MS worsening after stopping fingolimod}

Caterina Lapucci, Damiano Baroncini, Maria Cellerino, et al.

Neurol Neuroimmunol Neuroinflamm 2019;6;

DOI 10.1212/NXI.0000000000000566

This information is current as of April 16, 2019

Neurol Neuroimmunol Neuroinflamm is an official journal of the American Academy of Neurology.

Published since April 2014, it is an open-access, online-only, continuous publication journal. Copyright

Copyright $\left({ }^{\circ} 2019\right.$ The Author(s). Published by Wolters Kluwer Health, Inc. on behalf of the American

Academy of Neurology.. All rights reserved. Online ISSN: 2332-7812.

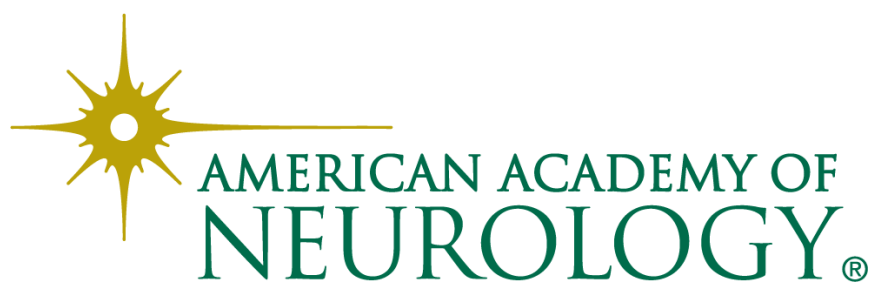




\section{Updated Information \& Services}

References

Citations

Subspecialty Collections

Permissions \& Licensing

Reprints including high resolution figures, can be found at: http://nn.neurology.org/content/6/4/e566.full.html

This article cites 10 articles, 1 of which you can access for free at: http://nn.neurology.org/content/6/4/e566.full.html\#\#ref-list-1

This article has been cited by 4 HighWire-hosted articles: http://nn.neurology.org/content/6/4/e566.full.html\#\#otherarticles

This article, along with others on similar topics, appears in the following collection(s):

Autoimmune diseases

http://nn.neurology.org//cgi/collection/autoimmune_diseases Burden of disease

http://nn.neurology.org//cgi/collection/burden_of_disease

Clinical neurology examination

http://nn.neurology.org//cgi/collection/clinical_neurology_examination

\section{MRI}

http://nn.neurology.org//cgi/collection/mri

Multiple sclerosis

http://nn.neurology.org//cgi/collection/multiple_sclerosis

Information about reproducing this article in parts (figures,tables) or in its entirety can be found online at:

http://nn.neurology.org/misc/about.xhtml\#permissions

Information about ordering reprints can be found online: http://nn.neurology.org/misc/addir.xhtml\#reprintsus

Neurol Neuroimmunol Neuroinflamm is an official journal of the American Academy of Neurology.

Published since April 2014, it is an open-access, online-only, continuous publication journal. Copyright

Copyright $\odot 2019$ The Author(s). Published by Wolters Kluwer Health, Inc. on behalf of the American Academy of Neurology.. All rights reserved. Online ISSN: 2332-7812.

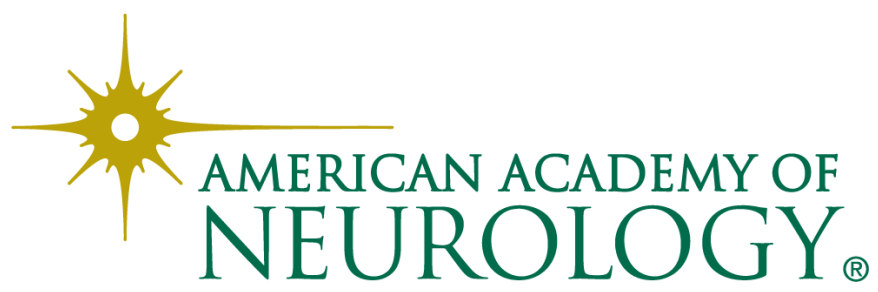

